\title{
Challenges of Electronic Banking in Case of Commercial Bank of Ethiopia, Wolita Sodo Dicha Branch
}

\author{
Addis Alemayehu Tekele (MBA) \\ Department of Management, Wolaita Sodo University, Po.box 138, Ethiopia
}

\begin{abstract}
The study aims at assessing Challenges of Electronic banking in commercial bank of Ethiopia, Wolita sodo Dicha branch. This research used descriptive type of research design which describes the performance and challenges of e banking as it is. The research employed both primary and secondary types of data and primary data were gathered through questionnaire that had both open and closed end questionnaires. The general populations of this research were 2532 e banking customers of Commercial Bank of Ethiopia Wolita sodo branch. The researcher employed convenient sampling technique since the research assumed only those customers who use electronic banking from the bank. The collected data was analyzed using descriptive statistics such as frequency and percentage. To exploit the benefit of E-banking system, the bank needs to familiarize its customers with the processes and benefits of the system. The bank should strengthen its ICT department through providing training to IT personnel and procuring required hardware and software. The lack of legal and regulatory framework for e-banking services has discouraged banks from introducing this innovative e banking technology. Thus, government should issue laws that govern electronic payment. This helps financial service providers introduce innovative products currently in use around the world which are cost effective, efficient and safe.
\end{abstract}

Keyword: E banking,

DOI: $10.7176 /$ JIEA/10-1-02

Publication date: January $31^{\text {st }} 2020$

\section{Introduction}

Information technology is becoming an important factor in the future development of financial services industry, especially the banking industry. The banking sector is based on sharing of information, which itself heavily relies on information and communication technology (ICT) in order to acquire, analyze and deliver data to all relevant users. (Imiefoh, P, 2012).

Many banks have adopted the "E-banking" concept for their day-to-day transactions which meets the expectations its internal users (employees) and external users (customers, suppliers, or institutional partners). A business can simplify or improve its human resources by introducing various internet technologies. Benefits include the improvement of administrative systems, better information tracking, and time and cost effectiveness. Under this condition, the transition to "E-banking" has become a necessity for banks: In one hand it offers the major opportunities in terms of competitive advantages.

A feature of the banking industry across the globe has been that it is increasingly becoming turbulent and competitive, characterized by an increasing trend towards internationalization, mergers, takeovers and consolidation of the banking industry. As a response and aided by technological developments, banks have attempted to build customer satisfaction through providing better products and services and at the same time to reduce operating costs. developments (Kesseven, P, et al, 2007).

Growth of Electronic banking in a country depends on many factors, such as success of internet access, new online banking features, household growth of internet usage, legal and regulatory framework. E-banking can offer speedier, quicker and dependable services to the customers for which they may be relatively satisfied than that of manual system of banking. E-banking system not only generates latest viable return, it can get its better dealings with customers (Nupur, J.2010).

\subsection{Statement of the Problem}

In this era of globalization, with increased competition around the globe in all sectors, a strong banking industry is important in every country and can have a significant effect in supporting economic development through efficient financial services; as a result many banks in the world are modifying their strategies to reach customers worldwide more easily and cheaply.

Therefore, banks are developing the technologies that will help them deliver banking products and services by the most cost-effective channels and one of such channel is adoption of e banking or internet banking. Ebanking is a way to keep existing customers and attract new ones to the bank. The transaction costs of providing these services are lower than the traditional approach. The rapidly growing information and communication technology is knocking the front door of every organization in the world (Booz \& Hamilton, 1997).

Electronic banking systems are rare in developing countries like Ethiopia where cash is still king. $21^{\text {st }}$ century has witnessed tremendous technology advancement in all spheres of human endeavor. The increasing advancement 
in information and communication technology has transformed the landscape of any business in the present world while this change is not unique to banking (Locket and Littler, 1997).

Particular challenges arise in trying to integrate new business model into the banking sector. It is for this reason that academic research is paramount in this emerging business model. In Ethiopia, most banks practicing E-banking are facing challenges such as customer preference for the e-banking facility, convenience of clients to utilize and adopt e-banking facilities. While numerous studies have been undertaken to examine issues in the wider context of e-banking and customer loyalty, comprehensive research in the area of e-banking issues and customer preferences in the specific context of this bank has been rather limited.

\subsection{Research Questions}

1. How the performance of e banking of commercial bank of Ethiopia, Wolita Sodo Dicha branch looks like?

2. What are the main problems related to E-banking of commercial bank of Ethiopia Wolita Sodo Dicha branch?

\subsection{General Objective}

- The general objective of this study is to assess the challenges of electronic banking in commercial bank of Ethiopia, Wolita Sodo Dicha branch ranch.

\section{Literature Review}

\subsection{Introduction to E-banking}

According to Mohammed S. (2008), electronic Banking is transforming the financial services industry through various innovations. The quantity of cross-border trading and other financial activities is increasing geometrically make possible by technology. It has been made possible by technology, particularly information technology to generate, collect and process information about bank operation and bank customers efficiently and effectively.

It provides the ability to create more effective systems of controls in individual institutions and in the market themselves. Compared to the paper based operation, Electronic Banking Systems, in its most proficient form, offer instant verification and transfer and reduces the flow of costly paper in the record keeping process. Application of technology in banking offer opportunity for reduction of both paper and people. Banks have developed electronic banking service for three main reasons.

- $\quad$ To protect and increase market share

- To reduce operating cost by substituting physical capital and technology for labor

- To generate new revenue

\subsection{Types, Benefits and Features of Electronic Payment Methods \\ 2.2.1 Benefits of E-Cards}

According to C.S.V Murthy, (2004), E-cards offer a number of benefits to the issuing banks and customers of the bank including:

- Dramatically reduce printing, mailing, and financial handling costs associated withprocessing transaction.

- Enhance payment security by minimizing theft or loss.

- Prevent fraud through automated controls

- Increase customer satisfaction and enhance service to constituents.

- Improve operational efficiency and profitability of the issuing banks.

\subsubsection{Mobile Banking}

Mobile banking (also known as M-banking or SMS banking) is a term used for performing balance checks, account transactions, payments etc. via a mobile device such as a mobile phone. Mobile banking is most often performed via SMS or the Mobile Internet but can also use special programs called clients downloaded to the mobile device.

\subsubsection{Tele Banking}

Tele banking refers to the services provided through phone that requires the customers to dial a particular telephone number to have access to an account, which provides several options of services (Rahman, 2006).

\subsubsection{Home Banking}

Home banking frees customers from visiting branches and most transactions will be automated to enable them to check their account activities, transfer funds and to open $\mathrm{L} / \mathrm{C}$ sitting in their desk with the help of a personal computer and a telephone (Rahman, 2006).

\subsubsection{Point of Sale Terminal}

An advanced payment system, which enables customers to use an ATM card to pay for goods and services, electronically debiting the cardholders account and crediting the account of the merchant (Rahman, 2006). 


\subsection{Empirical Evidence}

\subsubsection{Challenges and prospects of E-Banking Adoption}

\subsubsection{Challenges}

According to Rahman (2008) in Bangladesh despite huge demand from the business community as well as the retail customers particularly the urban customers, electronic banking

(e-banking) is still at a budding state due mainly to a number of constraints such as unavailability of a backbone network connecting the whole country; inadequacy of reliable and secure information infrastructure especially telecommunication infrastructure; sluggish ICT penetration in banking sector; insufficient legal and regulatory support for adopting e banking and so on. The concept of e-banking includes all types of banking activities performed through electronic networks. It is the most recent delivery channel of banking services, which is used for both business-to-business and business-to-customer transactions.

However, in true sense, e-banking includes activities like payment of bills and invoices, transfer of funds between accounts, applying for a loan, payment of loan installments, sending funds to third parties via emails or internet connections regardless of where the client is located. Leow, Hock Bee (1999) state that the terms PC banking, online banking, Internet banking, telephone banking or mobile banking refers to a number of ways in which customer can access their banks without having to be physically present at the bank branch. Therefore, ebanking covers all these ways of banking business electronically. Since e-banking offers some smart services benefiting both banks and customers compared with traditional banking system, it has become imperative to make necessary room for banks to flourish e- banking.

In addition, an exploratory study that was conducted in Zimbabwe by ChituraTofara (2008) indicated that incompatibility with the existing system, cost of implementation, security concerns, lack of expertise, inadequate legislation and consumer acceptance are the majorchallenges for the adoption of e-banking in the country's banking industry.

\subsubsection{Drivers and Barriers of E-Banking Adoption}

An exploratory research conducted by Mahdi Salehi (2004) in Iran indicate that the adoption status of e-banking is the transition of pre-development to development phase and the main drivers for adopting e-banking are downsizing, gaining competitive advantage, increasing market share and improving bank's image. The analysis further reveals that inefficient ICT infrastructure, political challenges and traditional organizational culture are barriers for adoption of e-banking.

In addition to the above factors, the case study that was conducted in china by SherahKurnia, FeiPeng, Yi Ruo Liu (2005) suggests that the government support is also a strong driver for e-banking adoption. The government support is manifested in two ways. Firstly, the

Government is establishing an electronic commerce (EC)-friendly environment in the country.

The government in recent years to revamp the national ICT and logistic infrastructures has committed heavy investments. New EC laws and regulations have also been passed and adjusted to provide legal protections for EC activities in general. Secondly, the government also directly offers financial incentives to promote e-banking adoption.

\section{Research Methodology}

Based on the purpose of the study, this research is descriptive type of research design which describes the performance and challenges of e banking as it is. The target populations of this research were e banking customers of Commercial Bank of Ethiopia Wolaita Sodo Dicha branch. Numerically, the total numbers of e banking users in the branch are 2532_(mobile banking 1012 and ATM 1520). The researcher was used Yamane's (1967) to calculate sample size. A sample of 345 customers was selected using convenient sampling technique since it is difficult and time taking to get all customers of e banking. From 345 distributed questionnaires 300 questionnaires were returned. Primary data was collected though both open end and close end Questionnaires from e banking users of the bank. The secondary data collected from report, records, brochures and news papers. The collected data was analyzed using descriptive statistics such as frequency, percentage and tabulation.

\section{Result and Discussions \\ 4.1 Results and Discussions of Electronic Banking Questions \\ Table 4.1 Service Interruption}

Does the bank have procedures in place for when there is an interruption in service of e banking (internet banking) for the customer?

\begin{tabular}{|l|l|l|l|}
\hline \multicolumn{1}{|c|}{ Variable } & \multicolumn{1}{c|}{ Frequency } & \multicolumn{1}{c|}{ Percent } & \multicolumn{1}{c|}{ Valid Percent } \\
\hline Yes & 79 & 26.3 & 26.3 \\
\hline No & 221 & 73.7 & 73.7 \\
\hline Total & 300 & 100.0 & 100.0 \\
\hline
\end{tabular}

Source: survey result 2019 
Table 4.1 shows whether the bank had procedures in the time where there is interruption in service of e banking for the customers. It depicts that $26.3 \%$ of the respondents reveals that there is a procedures to overcome internet banking service interruption while the rest $(73.7 \%)$ of the respondents said there is no adequate procedures in place for when there is an interruption in service of e banking (internet banking) for the customer. Hence, it can be concluded that most of the customers included in this survey didn't observe mechanism while there is service interruption in e banking.

Table 4.2 Channels of E Banking

What are the different electronic channels through which the bank is delivering the service to its customers? You can choose more than once.

\begin{tabular}{|l|l|}
\hline \multicolumn{1}{|c|}{ Variable } & \multicolumn{1}{c|}{ Tick here ( X ) } \\
\hline Internet banking & 178 \\
\hline ATM & 289 \\
\hline Telephone banking & 125 \\
\hline Mobile or SMS banking & 289 \\
\hline Others & 0 \\
\hline
\end{tabular}

Source: survey result 2019

The above table reveals different electronic channels through which the bank is delivering the service to its customers. As indicated in the table from the total respondents included in this survey 178 respondents use internet banking services, 289 respondents use ATM, 125 respondents use Tele banking, and 289 respondents use mobile or SMS banking. From the above discussion it can be concluded that many customers use ATM service from the bank.

Table 4.3 Option Available to Customers

What options are available to the customer once they have accessed e-banking?

\begin{tabular}{|l|l|c|}
\hline \multicolumn{1}{|c|}{ S. No. } & \multicolumn{1}{|c|}{ Variable } & Tick here ( X ) \\
\hline 1 & Fund transfer & $\mathbf{2 3}$ \\
\hline 2 & New account set-up & 0 \\
\hline 3 & Insurance premium payment & 0 \\
\hline 5 & Credit application & $\mathbf{2 9 9}$ \\
\hline 6 & Balance inquiry & $\mathbf{2 5 5}$ \\
\hline 7 & Bill presentment and payment & 300 \\
\hline 8 & Cash withdrawal & $\mathbf{2 5 6}$ \\
\hline 9 & Purchase of goods and services & 12 \\
\hline 10 & Utility payment & 0 \\
\hline
\end{tabular}

Source: survey result 2019

The above table depicts for what purpose customers use the service of e banking. As shown in the table from the total respondents included in the study 198 of the respondents uses for fund transfer purpose, 23 of the respondents uses for new account set-up, no respondents uses for insurance premium payment and credit application. On the other hand, 299 of the respondents uses for balance inquiry, 255 of the respondents uses for bill presentment and payment, 300 of the respondents uses for cash withdrawal, 256 of the respondents uses for purchase of goods and services and finally 12 of the respondents uses for utility payment.

Table 4.4 Adoption of the System

Do you think that the bank is sufficiently adopted the system?

\begin{tabular}{|l|c|c|c|}
\hline \multicolumn{1}{|c|}{ Variable } & Frequency & Percent & Valid Percent \\
\hline Yes & 74 & 24.7 & 24.7 \\
\hline No & $\mathbf{2 2 6}$ & 75.3 & 75.3 \\
\hline Total & $\mathbf{3 0 0}$ & $\mathbf{1 0 0 . 0}$ & $\mathbf{1 0 0 . 0}$ \\
\hline
\end{tabular}

Source: survey result 2019

As far as the adoption of the system is concerned, majority $(75.3 \%)$ of the respondents included in this survey believes that the bank didn't adopt the system sufficiently, while the rest $(24.7 \%)$ of the respondents believes the bank adopted the system sufficiently. From the above discussion most customers included in this survey believes that the bank didn't adopted the system sufficiently.

Following this question customers who say yes for the above question were asked to rate their degree of conformity to the following challenges with respect to the adoption of e banking in the bank. 


\subsection{Challenges of $E$ banking discussion \\ Table 4.5 Cost of Installation}

High installation cost

\begin{tabular}{|ll|r|r|r|r|}
\hline & Frequency & Percent & Valid Percent & Cumulative Percent \\
\hline Valid & S. disagree & 2 & .7 & .9 & .9 \\
& Disagree & 20 & 6.7 & 8.8 & 9.7 \\
& Neutral & 123 & 41.0 & 54.4 & 64.2 \\
& Agree & 37 & 12.3 & 16.4 & 80.5 \\
& S. Agree & 44 & 14.7 & 19.5 & 100.0 \\
& Total & 226 & 75.3 & 100.0 & \\
Missing & System & 74 & 24.7 & & \\
Total & & 300 & 100.0 & & \\
\hline
\end{tabular}

Source: survey result 2019

The above table shows customers degree of agreement to different challenges they may encounter while they deal with e banking in commercial bank of Ethiopia Wolaita Sodo Dicha branch. Regarding installation costs of the system, $14.7 \%$ of respondents strongly agreed that there are very high installations costs, $12.3 \%$ of respondents agree, $41 \%$ of respondents are indifferent, $6.7 \%$ of respondents disagree and $0.7 \%$ of respondents are strongly disagree that there are high installation cost. Hence, most respondent included in this research are indifferent about the issues under investigation.

Table 4.6 Customers' Demand

Lack of demand from the customers side

\begin{tabular}{|ll|r|r|r|r|}
\hline & & Frequency & Percent & Valid Percent & Cumulative Percent \\
\hline Valid & Disagree & 3 & 1.0 & 1.3 & 1.3 \\
& Agree & 18 & 6.0 & 8.0 & 9.3 \\
& S. Agree & 205 & 68.3 & 90.7 & 100.0 \\
& Total & 226 & 75.3 & 100.0 & \\
Missing & System & 74 & 24.7 & & \\
Total & & 300 & 100.0 & & \\
\hline
\end{tabular}

Source: survey result 2019

Concerning demand from the customers' side, majority $(68.3 \%)$ of the respondents strongly agreed that there is Lack of demand from the customers' side, $6 \%$ of the respondents agree, and $1 \%$ respondents disagree with the issue. From the above discussion it can be concluded that most respondents included in this study strongly believes that there is lack of demand from the customers' side.

Table 4.7 Chance of Risks

Chances of risk from the banks side

\begin{tabular}{|ll|r|r|r|r|}
\hline & Frequency & Percent & Valid Percent & Cumulative Percent \\
\hline Valid & S. disagree & 14 & 4.7 & 6.2 & 6.2 \\
& Disagree & 49 & 16.3 & 21.7 & 27.9 \\
& Neutral & 25 & 11.1 & 38.9 \\
& Agree & 78 & 26.0 & 34.5 & 73.5 \\
& S. Agree & 60 & 20.0 & 26.5 & 100.0 \\
& Total & 226 & 75.3 & 100.0 & \\
Missing & System & 74 & 24.7 & & \\
Total & & 300 & 100.0 & & \\
\hline
\end{tabular}

Source: survey result 2019

With respect to chances of risk from the banks side, $20 \%$ of the respondents strongly believe that there is chances of risk from the banks side, $26 \%$ of the respondents agreed, $8.3 \%$ of the respondents are indifferent, $16.3 \%$ of the respondents are disagreed and the rest $(4.7 \%)$ of the respondents strongly disagreed that there is chances of 
risk from the banks side. This indicates that most respondents included in this research believe that there is a chance of risk from the banks side.

Table 4.8 Educated and Efficient Staff

lack of educated and efficient staff in e-banking context

\begin{tabular}{|ll|r|r|r|r|}
\hline & Frequency & Percent & Valid Percent & Cumulative Percent \\
\hline Valid & S. disagree & 9 & 3.0 & 4.0 & 4.0 \\
& Disagree & 25 & 8.3 & 11.1 & 15.0 \\
& Neutral & 15 & 5.0 & 6.6 & 21.7 \\
& Agree & 25.7 & 34.1 & 55.8 \\
& S. Agree & 100 & 33.3 & 44.2 & 100.0 \\
& Total & 226 & 75.3 & 100.0 & \\
Missing & System & 74 & 24.7 & & \\
Total & & 300 & 100.0 & & \\
\hline
\end{tabular}

Source: survey result 2019

As far as lack of educated and efficient staff in e-banking context is concerned, $33.3 \%$ of the respondents strongly agreed that there is lack of educated and efficient staff in e-banking context, while $25.7 \%$ of respondents agree, $5 \%$ of the respondents are indifferent, $8.3 \%$ of respondents disagree, and the rest $3 \%$ of the respondents strongly disagree that there is lack of educated and efficient staff in e-banking context. So, it can be observed that most respondents included in this study strongly agree that there is lack of educated and efficient staff in e-banking context.

Table 4.9 legal and Regulatory Framework

Lack of suitable legal and regulatory framework

\begin{tabular}{|ll|r|r|r|r|}
\hline & Frequency & Percent & Valid Percent & Cumulative Percent \\
\hline Valid & S. disagree & 11 & 3.7 & 4.9 & 4.9 \\
& Disagree & 114 & 38.0 & 50.4 & 55.3 \\
& Neutral & 12 & 4.0 & 5.3 & 60.6 \\
& Agree & 52 & 17.3 & 23.0 & 83.6 \\
& S. Agree & 37 & 12.3 & 16.4 & 100.0 \\
& Total & 226 & 75.3 & 100.0 & \\
Missing & System & 74 & 24.7 & & \\
Total & & 300 & 100.0 & & \\
\hline
\end{tabular}

Source: survey result 2019

Regarding lack of suitable legal and regulatory framework, $12.3 \%$ of the respondents strongly agreed that there is lack of suitable legal and regulatory framework, $17.3 \%$ of the respondents agree, $14 \%$ of the respondents prefer to be indifferent, $38 \%$ of the respondents disagree and the rest $3.7 \%$ of the respondents strongly disagree that there is Lack of suitable legal and regulatory framework. From the above discussion it can be concluded that most respondents comprised in this survey disagreed that there is lack of suitable legal and regulatory framework. 
Table 4.10 Readiness of the Bank to Adopt the System

Non-readiness of banks to adopt the system

\begin{tabular}{|ll|r|r|r|r|}
\hline & Frequency & Percent & Valid Percent & Cumulative Percent \\
\hline Valid & S. disagree & 32 & 10.7 & 14.2 & 14.2 \\
& Disagree & 159 & 53.0 & 70.4 & 84.5 \\
& Neutral & 2 & .7 & .9 & 85.4 \\
& Agree & 13 & 4.3 & 5.8 & 91.2 \\
& S. Agree & 20 & 6.7 & 8.8 & 100.0 \\
& Total & 226 & 75.3 & 100.0 & \\
Missing & System & 74 & 24.7 & & \\
Total & & 300 & 100.0 & & \\
\hline
\end{tabular}

Source: survey result 2019

The other issue that the respondents asked was to rate their levels of agreement with respect to readiness of banks to adopt the system. The above table reveals that $6.7 \%$ of the respondents strongly agreed that there is no readiness to adopt the system from the banks side, $4.3 \%$ of the respondents agree and $0.7 \%$ of the respondents are indifferent. On the other hand, $53 \%$ of the respondents disagree and $10.7 \%$ of the respondents strongly disagree with respect to Non-readiness of banks to adopt the system. Thus, most participants encompassed in this survey disagreed with non-readiness of the bank to adopt e banking.

Table 4.11 Government Initiation

Lack of government initiation or lack of government prioritization

\begin{tabular}{|ll|r|r|r|r|}
\hline & Frequency & Percent & Valid Percent & Cumulative Percent \\
\hline Valid & Disagree & 73 & 24.3 & 32.3 & 32.3 \\
& Neutral & 25 & 8.3 & 11.1 & 43.4 \\
& Agree & 71 & 23.7 & 31.4 & 74.8 \\
& S. Agree & 57 & 19.0 & 25.2 & 100.0 \\
& Total & 226 & 75.3 & 100.0 & \\
Missing & System & 74 & 24.7 & & \\
Total & & 300 & 100.0 & & \\
\hline
\end{tabular}

Source: survey result 2019

Concerning Lack of government initiation or lack of government prioritization, $19 \%$ of the respondents strongly agreed that there is lack of government initiation or lack of government prioritization, $23.7 \%$ of the respondents agreed and $8.3 \%$ of the respondents are indifferent. On the other hand, $24.3 \%$ of the respondents disagree that there is no lack of government initiation or lack of government prioritization. From the above presentation of finding it can be determined that most participants included in the research believe that there is lack of government initiation or lack of government prioritization regarding the system.

Table 4.12 Absence of Financial Networks

Absence of financial networks that links different banks

\begin{tabular}{|ll|r|r|r|r|}
\hline & Frequency & Percent & Valid Percent & Cumulative Percent \\
\hline Valid & S. disagree & 6 & 2.0 & 2.7 & 2.7 \\
& Disagree & 7 & 2.3 & 3.1 & 5.8 \\
& Neutral & 2 & .7 & .9 & 6.6 \\
& Agree & 20.0 & 26.5 & 33.2 \\
& S. Agree & 60 & 50.3 & 66.8 & 100.0 \\
& Total & 151 & 75.3 & 100.0 & \\
Missing & System & 226 & 24.7 & & \\
Total & & 74 & 100.0 & & \\
\hline
\end{tabular}

Source: survey result 2019 
As far as Absence of financial networks that links different banks is concerned, $50.3 \%$ of the respondents are strongly agree that there is absence of financial networks that links different banks, $20 \%$ of the respondents agree and $0.7 \%$ of the respondents are indifferent about the issue. On contrary, $2.3 \%$ of the respondents disagree and $2 \%$ of the respondents are strongly disagreed with respect to the absence of financial networks that links different banks. Therefore, it can be concluded that most participants encompassed by the study believe that there is absence of financial networks that links different banks.

Table 4.13 Level of Internet Penetration

Low level of internet penetration and poorly developed telecommunication infrastructure

\begin{tabular}{|ll|r|r|r|r|}
\hline & Frequency & Percent & Valid Percent & Cumulative Percent \\
\hline Valid & S. disagree & 9 & 3.0 & 4.0 & 4.0 \\
& Disagree & 18 & 6.0 & 8.0 & 11.9 \\
& Neutral & 5 & 1.7 & 2.2 & 14.2 \\
& Agree & 29 & 9.7 & 12.8 & 27.0 \\
& S. Agree & 165 & 55.0 & 73.0 & 100.0 \\
& Total & 226 & 75.3 & 100.0 & \\
Missing & System & 24.7 & & \\
Total & & 300 & 100.0 & & \\
\hline
\end{tabular}

Source: survey result 2019

Concerning low level of internet penetration and poorly developed telecommunication infrastructure, $55 \%$ of the respondents strongly agree, and $29.7 \%$ of the respondents agree that there is low level of internet penetration and poorly developed telecommunication infrastructure, while $1.7 \%$ of the respondents are indifferent, $6 \%$ of the respondents are disagree and $3 \%$ of the respondents strongly disagreed with respect to the issue. From the above presentation, it can be determined that most respondents participates in this survey strongly believe that there is low level of internet penetration and poorly developed telecommunication infrastructure.

Table 4.14 Level of Initiation on the side of the Shareholders

Low level of initiation on the side of the shareholders to adopt the system

\begin{tabular}{|ll|r|r|r|r|}
\hline & Frequency & Percent & Valid Percent & Cumulative Percent \\
\hline Valid & S. disagree & 6 & 2.0 & 2.7 & 2.7 \\
& Disagree & 12 & 4.0 & 5.3 & 8.0 \\
& Neutral & 58 & 19.3 & 25.7 & 33.6 \\
& Agree & 56 & 18.7 & 24.8 & 58.4 \\
& S. Agree & 94 & 31.3 & 41.6 & 100.0 \\
& Total & 226 & 75.3 & 100.0 & \\
Missing & System & 74 & 24.7 & & \\
Total & & 300 & 100.0 & & \\
\hline
\end{tabular}

Source: survey result 2019

Regarding low level of initiation on the side of the shareholders to adopt the system, $31.3 \%$ of the respondents strongly agreed, $18.7 \%$ of the respondents agreed and $19.3 \%$ of the respondents are indifferent with respect to low level of initiation on the side of the shareholders to adopt the system. On the other hand, $4 \%$ of the respondents disagreed and the rest $2 \%$ of the respondents are strongly disagreed with low level of initiation on the side of the shareholders to adopt the system. From this discussion it can be concluded that most respondent participated in this research strongly believes that there is low level of initiation on the side of the shareholders to adopt the system. 
Table 4.15 Cost of Internet

High cost of internet

\begin{tabular}{|ll|r|r|r|r|}
\hline & Frequency & Percent & Valid Percent & Cumulative Percent \\
\hline Valid & S. disagree & 4 & 1.3 & 1.8 & 1.8 \\
& Disagree & 12 & 4.0 & 5.3 & 7.1 \\
& Neutral & 7 & 2.3 & 3.1 & 10.2 \\
& Agree & 53 & 17.7 & 23.5 & 33.6 \\
& S. Agree & 150 & 50.0 & 66.4 & 100.0 \\
& Total & 226 & 75.3 & 100.0 & \\
Missing & System & 74 & 24.7 & & \\
Total & & 300 & 100.0 & & \\
\hline
\end{tabular}

Source: survey result 2019

In relation to cost of internet, $50 \%$ of the respondents strongly agreed that there is high cost internet, $17.7 \%$ of the respondents agree, and $2.3 \%$ of the respondents are indifferent about the cost of internet. On contrary, $4 \%$ of the respondents disagree that there is high cost of internet, and the rest $1.3 \%$ of the respondents strongly disagreed with the issue. From the above discussion it can be concluded that most respondents encompassed in this survey strongly agreed that there is high cost of internet with respect to e banking.

Table 4.16 Coordination and Cooperation with the other Banks

Lack of coordination and cooperation with the other banks in e-banking context

\begin{tabular}{|ll|r|r|r|r|}
\hline & Frequency & Percent & Valid Percent & Cumulative Percent \\
\hline Valid & S. disagree & 6 & 2.0 & 2.7 & 2.7 \\
& Neutral & 4 & 1.3 & 1.8 & 4.4 \\
& Agree & 77 & 25.7 & 34.1 & 38.5 \\
& S. Agree & 139 & 46.3 & 61.5 & 100.0 \\
& Total & 226 & 75.3 & 100.0 & \\
Missing & System & 74 & 24.7 & & \\
Total & & 300 & 100.0 & & \\
\hline
\end{tabular}

Source: survey result 2019

The last question that participants of the research asked was to rate their agreement with respect to whether there is lack of coordination and cooperation with the other banks in e-banking context. From the above table it can be observed that $46.3 \%$ of the respondents were strongly agreed that there is lack of coordination and cooperation with the other banks in e-banking context, $25.7 \%$ of the respondents agreed, and $1.3 \%$ of the respondents are indifferent. On the other hand, only $2 \%$ of the respondents are strongly disagreed and said there is no lack of coordination and cooperation with the other banks in e-banking context. Therefore, it can be concluded that most respondents participates in this survey believes that there is lack of coordination and cooperation with the other banks in e-banking context.

Table 4.17 Risks involved in Adopting/ using electronic channels

Are there any risks involved because of adopting /using electronic channels for banking services to the customer?

\begin{tabular}{|l|l|l|l|}
\hline \multicolumn{1}{|c|}{ Variable } & \multicolumn{1}{c|}{ Frequency } & \multicolumn{1}{c|}{ Percent } & \multicolumn{1}{c|}{ Valid Percent } \\
\hline Yes & 155 & 51.7 & 51.7 \\
\hline No & 145 & 48.3 & 48.3 \\
\hline Total & 300 & 100.0 & 100.0 \\
\hline
\end{tabular}

Source: survey result 2019

The above table shows customers response to risks involved in using or adopting e banking services. As indicated, majority $(51.7 \%)$ of the respondents agreed that there are risks in adopting /using electronic channels of e banking services, while the rest (48.3\%) disagreed that there is no risks in using electronic banking. From the above finding it can be concluded that most respondent participates in this survey believes that there are risks in adopting /using electronic banking channels. 
Table 4.18 Types of Risks

\begin{tabular}{|l|l|c|c|}
\hline S/no. & \multicolumn{1}{|c|}{ Types of risks } & Frequency & Percent \\
\hline 1 & Transaction or operation risk & 142 & $\mathbf{9 1 . 6}$ \\
\hline 2 & Security risk & 152 & $\mathbf{9 8 . 1}$ \\
\hline 3 & Compliance or legal risk & 149 & $\mathbf{9 6 . 1}$ \\
\hline 4 & Reputation risk & $\mathbf{0}$ & $\mathbf{0}$ \\
\hline 5 & Strategic risk & $\mathbf{0}$ & $\mathbf{0}$ \\
\hline $\mathbf{6}$ & Others & $\mathbf{0}$ & $\mathbf{0}$ \\
\hline
\end{tabular}

Source: survey result 2019

The above table shows types of risks that customers normally faces when they adopt/ use e banking from the bank. It portrays that $91.6 \%$ (from 155 respondents who said there is a risks of using/ adopting) of the respondents said that transaction or operation risk associated with adoption, $98.1 \%$ of the respondents said there is security risks and $96.1 \%$ of the respondents said there is compliance or legal risk with respects to using/ adopting e banking in the bank.

\section{Concussion and Recommendation}

\subsection{Concussion}

* Most of the customers included in this survey didn't observe mechanism while there is service interruption in e banking and 178 respondents' uses internet banking, 289 respondents uses ATM, 125 of the respondents use Tele banking, 289 respondents uses mobile or SMS banking.

* The result also depicts that 198 respondents uses fund transfer, 23 respondents uses new account set-up, no respondents uses insurance premium payment and credit application, 299 respondents uses for balance inquiry, 255 respondents uses e banking for bill presentment and payment, 300 respondents uses for cash withdrawal 256 respondents uses for purchase of goods and services and only 12 respondents uses the system for the purpose of utility payment.

* Most of the respondents believe that the bank didn't adopt the system sufficiently. Factors (challenges) that imped the proper adoption of E banking as customers believed were lack of demand from customers' side, chance of risks from bank side, lack of efficient staff in e banking context, absence of financial networks that links different banks, low level of internet penetration and poorly developed telecommunication infrastructure, low level of initiation on the side of the shareholders to adopt the system, high costs of internet, lack of coordination and cooperation with the other banks in e-banking context.

* Respondent also indicated that there are risks in adopting /using electronic banking channels and these risks would be transaction or operation risk, security risk, compliance or legal risk.

\subsection{RECOMMENDATION}

- To exploit the benefit of E-banking system, the bank needs to familiarize its customers with the processes and benefits of the system.

- The bank should strengthen its ICT department through providing training to IT personnel and procuring required hardware and software.

- Ongoing efforts by the Ethiopia telecommunication corporation to expand ICT infrastructure should be encouraged by the government and gradually the corporation should try to reduce the service charge.

- Electronic payments are not recognized in Ethiopia legal system. Thus, government should issue laws that govern electronic payment. This helps financial service providers introduce innovative products currently in use around the world which are cost effective, efficient and safe.

- Security risk is the major challenge for the adoption of e-banking service in the banking industry. Therefore, the national bank of the country in collaboration with all banks in the country should prepare typical security technologies applicable to control system networks such as firewall, intrusion detection and prevention etc.

\section{REFERENCES}

Adewuyi, I. D. (2011) Electronic Banking In Nigeria: Challenges Of TheRegulatory Authorities And The Way ForwardInternational Journal of Economic Development Research and Investment, Vol. 2 No. 1; April 2011 Abiy D. (2008, March, 17). Capital, weekly newspaper, Addis Ababa

Alhaji Ibrahim H. (2009). Understanding the e-payment system in Nigeria

Binyam T. (2009, February, 20). Daily Monitor, Addis Ababa.

Business in Ethiopia, Dashen bank payment news, Dashen bank (www.dashenbanksc.com), retrieved on April, 2015 ,

Business in Ethiopia, United bank (www.hibretbank.com), retrieved on April, 2010 
Chang Y.T. (2003) "Dynamics of Banking Technology Adoption: An Application to Internet Banking, Department of Economics", Workshop Presentation, University ofWarwick, Coventry, UK..

C.S.V. Murthy(2004). "E-commerce, Concepts, models and Strategies(ed), Himalya Publishing House,

Daniel E, Storey C (1997) On-line banking: Strategic and Management Challenges Pergamum. PII: 4-5 (S002463010007).

Isaac Awuondo (2005). The Future of e-Banking in Africa.

Juniper (2010), http://www.juniper.net/us/en/whitepapers-control system cyber vulnerabilities and potential mitigation of risk for utilities, retrieved on April, 2010.

Lockette A, Littler D (1997) The adoption of direct banking services. Journal of Marketing Management. 13:791811.

Leow, Hock, Bee (1999). New Distribution Channels in Banking Services, Bankers Journal Mahdi Salehi(2004). E-Banking in Emerging Economy: Empirical Evidence of Iran (Corresponding author) Accounting and Management Department, Zanjan University, Iran

Ma Zhiyong, TewodrosHailemeskel, Li Xiaojin (2008). National Network Operation Center for Ethiopian Telecommunications Corporation

Mishra R and J. Kiranmai (2009). "E-Banking: A Case of India", TheIcfai University Journal of Public Administration, Vol. 5, No. 1, pp. 55-65, 2009.

Mohammad MizanurRahman (2008). E-Banking in Bangladesh: Some Policy Implications.

Mols, Niels. (1998). The Behavioral Consequences of PC banking, International Journal of Bank Marketing, pp. 195-201.

Mohammed shamsuddoha (2008). Development of electronic banking service in Bangladesh, journal of Business Solutions, Vol. 1, No.2.December 2008

Mumbai.Daniel, E. (1999). "Provision of electronic banking in the UK and Republic of Ireland", International Journal of Bank Marketing, Vol. 17 No. 2, pp.72-82.

Nath R. and Shrick P. and Parzinger M. (2001). "Bankers Perspectives on Internet Banking”, e-Service Journal, Indiana University Press.

Rahman, M.(2006). Innovative Technology and Bank Profitability: The Bangladesh Experience.

Shah and Clarke (1997). E-Banking-Management-Issues-Solutions-and-Strategies

Singh, B. and Malhotra, P. (2004). Adoption of Internet banking: An empirical investigation of Indian banking Sector.Journal of Internet Banking and Commerce, 9 (2).

United Nations Conference on Trade and Development (UNCTAD) (2002). E-Commerce and Development Report 2000 (New York \& Geneva: United Nations

Young, R. D., Lang, W. W., \&Nolle, D. L. (2007). How the Internet affects output and performance at community banks. Journal of Banking \& Finance, 31, 1033- 1060

Zikmund, W.G. (2000). Business research methods (3rd ed), for worth: Harcourt college 